\title{
Techno-Savvy Millennials : A Booming Consumer Segment of India
}

\author{
Effulgence \\ Vol. 16 No. 1 (Special Issue 2) \\ January - June, 2018 \\ Rukmini Devi Institute of Advanced Studies \\ E-mail : effulgence@rdias.ac.in, Website : www.rdias.ac.in \\ http://effulgence.rdias.ac.in/user/default.aspx \\ https://dx.doi.org/10.33601/effulgence.rdias/v16/iSpl2/2018/32-39
}

\section{Dr. Reetika Jain ${ }^{1}$}

\begin{abstract}
PURPOSE OF RESEARCH:

Consumer market segments are continuously defined and redefined with the changing needs, buying patterns, media exposures, and unparalleled invasion of technology in consumers' lives. Millennial and Generation Z are the new booming consumer segments that are attracting the businesses. Presently, they are one of the most connected consumer segment.
\end{abstract}

Whereas Generation $Z$ are the consumers born after year 2000, millennials are those born between 1980-2000. Firms are therefore, tapping millennials who happen to be more independent as of today as compared to Generation Z. Studies highlight that this segment is characterised by avid researchers, information seekers, rely on peer reviews, more active on social media and blogs. In this digitalisation era, it becomes quintessential to tap this growing unexplored segment especially with digital marketing strengthening its roots in India.

\section{RESEARCHMETHODOLOGY:}

Present study explores the pertinent secondary data from some crucial consumer market reports to provide an insight into the buying behaviour of millennials in India vis-à-vis global millennials. It is also compared with the behavioural pattern of millennials globally.

\section{RESULTS AND IMPLICATION:}

The study provides consumer industry an insight into the peculiar behaviour of Indian millennials. It is evident from the studies that this segment of consumers is a booming one given the large population of India. They are also the most digitized consumer segment. Thus, it is a win-win situation for the companies given the size of this segment and the digital boom in India. Study also discusses the strategies for the businesses to harness the full potential of this untapped market.

Keywords: Indian Millennials, technology, consumer market segment, digital marketing.

\section{Assistant Professor, Hansraj College, DU, reetikajain29@yahoo.com}




\section{INTRODUCTION}

G eneration $\mathrm{Y}$, generation me, global generation, the net generation, echo boomers (children of baby boomers), gen next... all these terms refer to millennials. Companies have been long waiting for the millennial segment of global population to bloom. And the time has just arrived...Millennials, those born between 1980-2000, are today in the age bracket 18-38 years. They are now the full-fledged consumers with unique characteristics that differentiate them from other segments. They are the largest, best-educated generation in history. Millennials globally represent a sizable demographic, ranging from $11 \%$ of the population in ageing Japan, to $18 \%$ in markets, such as Vietnam and South Africa, to as high as 31\% UAE. In actual terms, the millennial population is highest in India, at 209 million, followed by China at 193 million and US at 43 million. Other large millennial markets are Indonesia, Brazil and Russia. Given the size of the millennial population in these markets, entities world over are wooing them as a key to business success. Though the millennial population is largest in developing countries (India and China) but their potential is limited due to the low average incomes per person. In contrast, Switzerland, Norway and Denmark have highest income in millennial segment. But they have small millennial population. Still there are markets with a good balance between population size and income. US happens to have a large millennial population that is earning relatively well on an international standards. Japan, Germany, UK and France are other such countries. Among developing markets, Brazil and Mexico fits in this category.

In many developing markets, millennials are an unusually wealthy generation, surpassing the incomes of their parents and grandparents and they are keen to demonstrate this. India and China are perfect example. Though millennial earn low wages here, they are rich compared to their elders. In developed markets, the opposite pattern holds true. Millennials are poor compared to their parents and face challenges like high unemployment, student debt burdens, unaffordable housing, low wages and unstable jobs in zero hours contracts. This impact is more on young millennial group (in age 20-29) than on the older millennials (in the age group 30-38) who are typically earning a much better salary.

Millennials are also a diverse group of people, from the 20 year-old rural Indian mother to the wealthy 29 year-old tech entrepreneur in Shanghai. Cultural differences are predominantly reflected in the millennials personality types. Yet, there are some commonalities between most millennials globally. This group is more homogeneous than older demographics, due to the strong influence of internet. According to Euromonitor International's Global Consumer Trends Survey, around three quarters of internet connected consumers aged under 30 years own a smartphone and $24 \%$ of them spend more than three hours a day using their phones.

Dubbed "digital natives", this generation has grown up with the internet and is highly attached to their smartphone, in particular, are on social media all through the day. As a result, millennial world over have same cultural icons and lifestyle trends.

The uniqueness of Millennial consumers stems from their amazing awareness and adoption of digital technology, especially with mobile devices. Millennia's digital engagement is unprecedented compared to other cohort groups. Millennial are an unfocused audience. They are per se not loyal to just one digital communication service. But this doesn't mean Millennial are consuming less content. They are engaged with numerous digital services throughout the day as market is flooded with plethora of digital market service providers to choose from. As a result millennial are choosing many digital service at one point of time. Millennial are thus, accommodating all new technologies in their lives. For brands, this poses both challenge and opportunity. This consumer cohort is more fluctuating in their choices than any other consumers 
group. Millennials, however, are also willing to broaden the number of services and apps. Each digital channel therefore, represents a key engagement point for brands, marketers and advertisers to interact with this budding group of consumers. Moreover, these new digital channels are not cannibalizing the existing one because millennial are smart accommodators. Thus, millennial are a coveted demographic for marketers in just about any industry, and e-commerce is no exception as this age segment has grown up in the digital era The way they spend, shop, consume media and interact with one another-and-brands is therefore, worth analysing.

\section{MILLENNIALS AND THE DIGITAL WORLD}

Millennials approach to the digital world varies significantly from other cohorts. An insight into millennials pattern of technology usage can help brands to understand and engage with them successfully. Otherwise, marketers may be unsuccessful in influencing millennials to spend on their brands. Millennials are engaged with digital services all through the day and therefore dependent on their devices. They use smartphones for time and location specific information, accessing social media, camera function, music and texting, gaming etc. They rely on desktops or laptops for long form information such as reading blogs, watching video, checking forums and sending emails. Millennials are willing to "like" or "follow" a brand. But this relationship with brands on social media is aimed to get access to deals, coupons and specialised information and does not necessarily translate into brand loyalty or acting as crusader for the brands. They use their phones for browsing future purchases, price comparisons, but they are not willing to complete a purchase via phone as they prefer a larger screen and are sceptical of security issues. Yet, they are not frustrated by slow loading mobile sites, poor connections or difficulty entering payment information as against the older cohorts.

Millennials desire varies with culture. Yet, they all want experiences rather than "things", good value for money, brands are personalised in interaction. Millennials are also referred as "nowners". Millennials typically like to possess few core product categories, such as technological gadgets and clothing. With the boom of sharing (rental) economy and the downloaded media, millennials do not want to own things like music, films and games that can be accessed via the internet, while products such as cars can be hired on rental when needed. Thus, millennials are inclined towards minimalistic possessions and are conspicuous anti-materialistic in nature. While many millennials may be thought to be self-obsessed, re-using, recycling and charity are appealable virtues for them and are also concerned about the environment and social justice. It is, therefore, important for brands and companies to be transparent about their ethical stances while dealing with millennials.

Millennials are largely an unfocused audience, and therefore, not loyal to specific media. They are typical bargain hunters but using technology and internet to access different price comparison platforms. Euromonitor International found that $47 \%$ of millennials plan to increase their level of savings. Millennials are however, very willing to spend on gadgets, clothes, health and fitness and life experiences (such as travelling). But, they seek products that are customised or personalised. Similarly, they want brands that are interactive, responsive and relatable to them. They are more influenced by their peers, celebrities and vloggers and reject traditional advertising and promotion media.

\section{INDIAN MILLENNIALS}

Indians under 35 represent $35 \%$ of its population. Millennials also represent the largest cohort of workers in many organizations today. This makes how they think and act vital for the economy and society. They have created one of the largest IT startup ecosystems in the world $-72 \%$ of dotcom founders in India in 2015 were under 35 years of age. 
The Millennials comes on the cusp of far-reaching changes in India's business landscape, where connectivity for a billion Indians is the aim of companies like Reliance Jio and its partners.

While earlier generations migrated to digital media, millennials were the first to be digital natives. They grew up with this stuff and are certainly more comfortable with technology than their parents. This tech, lifestyle and social landscape has not only defined how these people work but how they play, shop and aspire to greater things. For instance, millennials work full time but remotely from another country. The company, which employs several dozen professionals, has no office. All work is done online in real time over Skype, WhatsApp and other file-sharing platforms. The team meets annually for an offsite and occasionally for meetings in wi-fi-enabled temporary offices. Increasingly, teams come together around projects and disband when these are over. Similarly, Generation X bought tickets and hotel bookings from travel agents and groceries from the corner store. But for millennials all that is history. Smart devices and digital landscapes have changed the way in which this demographic thinks, feels and wants. They're comfortable with the changing business landscape in India, happy to reach out locally as the well globally. Updating skills and learning new approaches are their key mantras for sustainability in competitive world. It makes them highly flexible, in thinking and action, to adapt to the ever-changing job market and social environment. As a result, many in this cohort are moving to be the first generation entrepreneur in their families.

By 2021 millennials will be $64 \%$ of the Indian workforce. They are very clear with their priorities in life. They want a better work life balance, are keen to learn and advance - not only for personal progression but to change the world in which they live. They're not looking to hang around either. Indian millennials like new things that improve their way of life and their thirst isn't just confined to the borders of their own country. They are global creatures, as much at ease in engaging with their neighbours as they are in reaching out to new friends and associates across the globe. The Deloitte India survey shows that millennials are twice as likely as their parents to start their own business. Universal Global also found that it's not just about higher salaries - today's millennials want to coach and mentor as well, contributing positively to the world around them.

\section{INSIGHT INTO INDIAN MILLENNIALS BEHAVIOUR}

India's millennial population is one of the largest in the world. Given the size of this 400 million cohort and growing further, they are fast becoming the driving force behind India's evolving mobile economic revolution. They have disposable income, a strong reliable internet connection and represent $35 \%$ on India's population. They are better educated and more tech savvy than their predecessors and are more likely to engage and shop online. At present, they are the largest consumer segment in India shopping online via mobile devices. Thanks to era 3G and 4G broadband connectivity, reliable and secure internet services. All this has revolutionized the business landscape in India. Indian Millennials could become the largest disruptive force in India for years to come (Morgan Stanley report).

Table 1 : India Millennials as Percentage of Total Population

\begin{tabular}{|c|c|}
\hline Year & \% of Total Population \\
\hline 2016 & 31 \\
\hline $2018 E$ & 33 \\
\hline $2020 E$ & 36 \\
\hline $2025 E$ & 42 \\
\hline
\end{tabular}

Source: UN, Morgan Stanley Research; E = estimate 
India's very large population is comparatively younger to that of U.S. and large European countries. Further, it is also expected that India's share of millennials will continue to increase by about half a percentage point through 2032. Demographically, India is also peculiar vis-à-vis other Asian economies who are largely facing the problem of declining working-age population. Added to this, India's millennials are better educated, better connected to information and better connected to the world than their predecessors in prior generations. However, India's current per capita income is $\$ 1,700$. This is far that of other emerging markets, such as China and Brazil. But, the silver lining is its GDP, which is forecasted to increase from an estimated \$2.2 trillion in 2017 to around \$5 trillion in 2025 as predicted by Morgan Stanley Report. It is also estimated that its per capita annual income will rise to $\$ 3,650$ in the next eightyear. Thus millennials in India are fast becoming a part of a rising middle income group. Three new Internet users are added every second in India. Technology adoption is inevitable for this cohort in India. They are immersed in a world of devices and content. Added to this, is the ever growing infrastructure that makes it affordable and efficient to be online anywhere and anytime. Factors like, the expected increase in the number of Indian millennials, their overall share in India's population, their growing spending ability and embrace of the Internet is providing a perfect blend of ingredients to make Indian millennials, a powerful economic force.

Table 2 : Devices used to access Internet

\begin{tabular}{|c|c|}
\hline Devices used & \% of time spend online \\
\hline Smart phones & 89 \\
\hline Laptop/Desktop & 9 \\
\hline Tablets & 2 \\
\hline
\end{tabular}

Source: AlphaWise, Morgan Stanley Research

The country's Internet service is becoming more pervasive and reliable. As smartphone prices drop and telecom infrastructure improves, Morgan Stanley estimates that the current $38 \%$ countrywide Internet penetration will increase to $60 \%$ by 2020, with $90 \%$ of them connected by smartphones. The price of $4 \mathrm{G}$ handsets have dropped more than 35\% since mid-2015, and mobile broadband penetration could increase from $17 \%$ of the total population today to about to about $50 \%$ in 2020 . Millennials, by that time, are projected to comprise $36 \%$ of India's total population, and estimated to account for $61 \%$ of its Internet users and $78 \%$ of its online shoppers.

Table 3 : Activities on which India Millennials Spend Time Online

\begin{tabular}{|c|c|}
\hline Activities & \% Time spend online \\
\hline Email/ Social media & 35 \\
\hline Browsing & $\mathbf{2 3}$ \\
\hline Entertainment (music/ vedios) & $\mathbf{3 0}$ \\
\hline Transactions (including banking) & $\mathbf{1 2}$ \\
\hline
\end{tabular}

Source: AlphaWise, Morgan Stanley Research

According to the AlphaWise survey, India's Millennials on an average spend 17 hours online weekly. They spend two thirds of that time emailing, browsing social media and conducting searches.
Only $11 \%$ of that time is spent on online transactions, including banking.

The ability to buy anywhere, anytime, with a wide 
assortment of available products at attractive prices is what hooking Indian millennials to online shopping according to the AlphaWise survey. Some online shoppers are influenced in their purchase decision by the reviews posted online and end up buying that product, even if it wasn't the product they originally planned to buy.

Table 4 : Criteria Indian Millennials Use to Buy Online

\begin{tabular}{|l|c|}
\hline Criteria & $\%$ \\
\hline Buy low cost & 12 \\
\hline Buy regular product/ brands & 23 \\
\hline Buy on basis of best review but within budget & 29 \\
\hline Buy on the basis of good review & 24 \\
\hline Buy new product on some trustworthy recommendations & 21 \\
\hline
\end{tabular}

Source: AlphaWise, Morgan Stanley Research

Among the potential beneficiaries of the rise of India's Millennials are mobile service providers and online retailers. Sectors with still low rates of usage, includes many content and service providers. They can harness their future potentialities to exploit this segment to full. Many traditional players, ranging from brick-and-mortar-only retailers to banks and beyond are likely to face the disruptive consequences of the Millennials' rising influence and market clout.

Millennials in India use both online and offline methods to make final decision to purchase. This includes browsing numerous apps, searching bricks and mortar store to square down at a product and its brand. $60 \%$ of millennials desire brands they can personally identify and make them stand apart from their peers. This necessitates brands to alter their marketing strategies by creating a message that is more engaging and has deeper impact on the millennials.

\section{STRATEGIES AND CONCLUSION}

$35 \%$ of the millennials in India have their own startup firms. Added to this, is their unquenching thirst for knowledge (from the plenty of resources at hand via internet). They are one of the most well-informed cohort groups. So, the traditional marketing methods like banner and TV ads are outdated for the tech savvy and marketing smart millennials.

Millennials want a direct, short and compelling reason for buying a brand via message. Such message content should not be hidden in mysticism or emotion as they are busy and have short attention spans. So, remaining focused in the message strategy works in favour of the marketers in targeting millennials. Millennials are the buzzing consumer segment. They talk and engage online via social media. Therefore, advertisers should ensure to get millennials creating a buzz around the ad to win their heart.

Millennials are largely the online purchasers even in India. Therefore, to reach this group, the marketers need to have online presence. Easy to navigate websites, wide variety at the end of online marketers, amazing deals, easy completion of transaction window etc. can keep these millennials hooked to a particular online marketer.

Quality and service are of paramount importance to millennials when choosing a brand for the product. Marketers therefore need to be sleek, provide easy of access, be highly responsive and designed to help them. Otherwise, millennials are very quick to go to next competitive brand that is ready to serve them well. As a result, today entities have drastically improved in serving this well-informed segment. 
Finally, millennials are constantly redefining the landscape because of their urge to learn and change. So, marketers also need to be on their toes. They should at least try to keep pace with the millennials and if possible, be ahead of them. Only then can businesses think of winning the marketing battlefield.

The consumer world is changing at a fast pace and marketing effectively to millennials in India can be rewarding for marketers. Indian marketers, therefore, need to adapt to the changing demographics and behavioural profiling of Indian consumers. Firms evolving winning marketing strategies to target India's millennials stand to benefit locally as well as globally.

\section{REFERENCES}

1) DAWN, B. VALENTINE, POWERS, L. THOMAS (2013), "Online product search and purchase behavior of Generation Y". Atlantic Marketing Journal, Vol. 2, Iss. 1, Article 6.

2) DAWN, B. VALENTINE, POWERS, L. TOMAS (2013), "Generation Y values and lifestyle segments". Journal of Consumer Marketing, 30/7 597-606

3) DONNELLY, CRISTOFER, SCAFF, RENATO (2013), "Who are the millennial shoppers? And what do they really want?" Accenture Outlook. http://www.accenture.com/

4) EUROMONITOR INTERNATIONAL (2015), "The impact of Millennials' consumer behaviors on global markets". http:/ / blog.euromonitor.com/2015/12/theimpact-of-millennials-consumer-behaviors-onglobal-markets.html

5) GAUZENTE, CLAIRE, ROY, YVES (2011), "Message Content in Keyword Campaigns, Click Behaviors, and Price-Consciousness: A Study of Millennial Consumers". Journal of Retailing and Consumer Services, 19 (1), 78-87

6) HERSHATTER, ANDREA, EPSTEIN, MOLLY (2010), "Millennials and the world of work: an organization and management perspective".
Journal of Business Psychology,Vol. 25, No. 2, pp. 211-223

7) JACKSON, VANESSA, LESLIE STOEL, AQUIA BRANTLEY (2011), “Mall Attributes and Shopping Value: Differences by Gender and Generational Cohort". Journal of Retailing and Consumer Services, 18 (1), 1-9

8) MCMAHAN, CAROLINE, HOVLAND, ROXANNE, MCMILLAN, SALLY (2009), "Online marketing communications: exploring online consumer behaviours by examining gender differences and interactivity within internet advertising". Journal of Interactive Advertising, Vol. 10, No. 1 (Fall, 2009), pp. 61-76

9) MILLER, RICHARD, WASHINGTON, KELLY (2012), "Millennial Consumers". In: Consumer Behavior 2012, Chapter 49, [e-book]: Richard K. Miller and Associates, pp. 250-255

10) ORDUN, GOEVEN (2015), "Millennial (Gen Y) Consumer Behaviors, Their Shopping Preferences and Perceptual Maps Associated with Brand loyalty". Canadian Social Science, 11(4), 40-55

11) Radojka Kraljević, Zrinka Filipović GENDER DIFFERENCES AND CONSUMER BEHAVIOR OF MILLENNIALS Acta Economica Et Turistica, Vol 3 (2017), No. 1, pp. 1-13

12) REISENWITZ, H. TIMOTHY, IYER, RAJESH (2009), "Differences in generation $X$ and generation Y: Implications for the organization and marketers". The Marketing Management Journal, 19 (2), 91-103

13) RODGERS, SHERRY, HARRIS, MARY ANN (2003), "Gender and e-commerce: An exploratory study". Journal of Advertising Research, 43(3), 322-329 STEIN, JOEL, SANBURN, JOSH (2013), "Why Millennials will save us all". Time International (Atlantic Edition), 181(19), pp. 26-33

14) SWEENEY, RICHARD (2006), Millennial Behaviors \& Demographics. University Heights, Newark, NJ: New Jersey Institute of Technology, 07102-1982 973-596-3208

15) SYMPHONY (2013), “Digital-first Millennials put a premium on value, engagement". 
http:/ / www.emarketer.com/Article/DigitalFirst-Millennials-Put-Premium-on-Value

16) TAYLOR PAUL, KEETER SCOTT (2010), Millennials: A Portrait of Generation Next: Confident, Connected, Open to Change. Washington, DC: The Pew Research Center

17) https://www.morganstanley.com/ideas/indiamillennials-makeover-disruption-growth 